\title{
Soaking time of lime solutions (Citrus aurantifolias) against the metal content reduction of cadmium in green shellfish (Perna viridis)
}

\author{
Arie Dwi Alristina, Dewinta Hayudanti, Rizky Dzariyani Laili, Rossa Kurnia Ethasari \\ Department of Nutrition, Institute of Health Science Hang Tuah Surabaya, Surabaya, Indonesia
}

\section{Article Info}

\section{Article history:}

Received Apr 23, 2021

Revised Aug 15, 2021

Accepted August 24, 2021

\section{Keywords:}

Cadmium

Lime

Mussels

Soaking time

Shellfish

\begin{abstract}
Indonesia has the potential for large marine and fisheries resources, reaching 23.26 million tons per year. Green shellfish (Perna viridis) are a source of animal protein that can be classified as Complete Protein because of its high levels of essential amino acids. These green shellfish are cheaper than other seafood products. However, heavy metals can be absorbed by shellfish, which is cadmium $(\mathrm{Cd})$ which if consumed can accumulate in the body, cause health problems and lead to death. Therefore, research is needed to reduce cadmium levels in green shellfish, including using a lime solution (Citrus aurantifolia). This study was to determine the effectiveness of the soaking time of lime in reducing the cadmium levels in green shellfish. The research was an experimental with a pretest-posttest group design. Kruskal Wallis and Mann Whitney test was used to analyze data by SPSS. The results showed a significant difference $(\mathrm{p}<0.05)$ that means the longer the soaking time, the longer the time for the citrate ions to react with metal cadmium, more cadmium is bound to the lime solution. It showed that soaking green shellfish with lime solution for 120 minutes was the most effective to reduce $73.77 \%$ of cadmium levels in green shellfish.
\end{abstract}

This is an open access article under the CC BY-SA license.

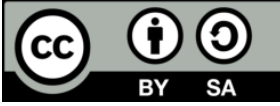

\section{Corresponding Author:}

Arie Dwi Alristina

Department of Nutrition

Institute of Health Science Hang Tuah Surabaya

Kec. Wonokromo, Surabaya, West Java 60244, Indonesia

Email: ariedwia@ stikeshangtuah-sby.ac.id

\section{INTRODUCTION}

Nutrients are elements that are contained in food and provide benefits for human health. Each food ingredient contains different nutrients. The amount and composition of nutrients can be contained in large amounts in one particular type of food, but can only be contained in very small amounts in other types of food. Shellfish is one of the marine biotas which is very rich in nutrients that the body needs. The nutritional content contained in shellfish is almost the same as other marine life. Nutrients in shellfish include protein, fat, carbohydrates and many others in a small composition [1].

Shellfish is a significant part of the global seafood or marine product market. Clams, scallops, oysters, mussels, shrimp, squid, crabs, lobsters, snails, crayfish, cuttlefish, and other sea animals can be found. Shellfish is an animal protein source that can be categorized as complete protein due to its high quantities of essential amino acids, which vary from 85 to $95 \%$. Amino acids with the highest amount per 100 grams are $3.474 \mathrm{mg}$ of glutamate; $2.464 \mathrm{mg}$ of aspartate; $1.909 \mathrm{mg}$ of lysine; $1.864 \mathrm{mg}$ of arginine and 1.798 of leucine. In shellfish also contains vitamin B12 which is high around $98.9 \mathrm{mg} / 100 \mathrm{mg}$. Vitamin B12 is very useful for maintaining heart health, stabilizing body temperature, stabilizing body $\mathrm{pH}$, aiding in 
digestion, maintaining a healthy nervous system and forming bone cells. Nutrients in shellfish offer various of health advantages to its consumers [1].

Although shellfish are generally safe to eat, their exposure to diverse environmental conditions, the filter nature of shellfish (oysters, clams, and mussels), and poor cultivation and handling procedures may generate health risks due to the presence of numerous contaminants. At various phases of harvest, farming, processing, packaging, storage, distribution, and consumption, the majority of dangers can be addressed with the appropriate preventive measures. Furthermore, government, international, and public health agencies closely monitor the safety of shellfish and other seafood for consumers [1].

A large number of research conducted in the last 30 years have convincingly demonstrated the favorable health effects of shellfish and seafood diet in humans. Seafood consumption, particularly shellfish with high omega-3 fatty acid concentration, has been related in numerous studies. Shellfish has nutritional benefits because to the high-quality protein, vitamins, and other critical components it contains. However, a number of studies, particularly those conducted in recent years, have indicated that the unavoidable presence of environmental pollutants in fish and shellfish can provoke a health risk to some of its consumers [2].

According to the Food and Agriculture Organization's (FAO) 2014 State of World Fisheries and Aquaculture report, 167.2 million metric tons (MMT) of seafood were available globally, with shrimp, lobsters, and cephalopods producing 3.5, 0.16, and 4.3 MMT, respectively. Concerning sustainability, sluggish stagnation of fisheries, increased consumer demand, and overall product safety have recently confronted the seafood business. Since 2012, the price of shellfish, one of the most important seafood commodities, has remained constant [1], [3]. A part of the EU-funded ECsafeSEAFOOD project database aids the seafood and aquaculture businesses in gathering data on pollutants and putting in place safety measures for seafood products [4].

Indonesia has the potential for large marine and fisheries resources. Marine production reaches 23.26 million tons per year. However, there is not much information on how much protein contribution from marine products consumed by the population towards the recommended adequacy of protein consumption. The consumption of marine products in Indonesia's population is $46.49 \mathrm{~kg} / \mathrm{cap} / \mathrm{year}$. In this case, green shellfish can also contribute to increase protein consumption per capita. Green shellfish are known as one of the marine animals that are useful as a source of animal protein and are very cheap when compared to other marine products such as fish, shrimp and squid. Green shellfish have excellent nutritional content, consisting of $40.8 \%$ water, $21.9 \%$ protein, $14.5 \%$ fat, $18.5 \%$ carbohydrates and $4.3 \%$ ash [5].

Green shellfish (Perna viridis) are often known as "green mussels", a type of shellfish that is widespread in Indonesian waters and is found in abundance in coastal areas, mangroves and river estuaries. This green shellfish is a mollusk animal that has long been known by the public. In Indonesia, this species is found in abundance from March to July in tidal and subtidal areas, living in groups and sticking firmly to hard objects such as wood, bamboo, stone or hard substrates [6]. Green shellfish are able to survive, settle and are as a filter feeder. This means that these shellfish absorb all the material around them not only for food (plankton), but also absorb harmful heavy metals.

Shellfish in Indonesian waters are also often contaminated by heavy metals such as cadmium and mercury. The heavy metal that pollutes marine waters in Indonesia is cadmium $(\mathrm{Cd})$. Cadmium $(\mathrm{Cd})$ is a dangerous heavy metal because it has a high risk of blockage and blood vessel disorders. Consumption of foods containing cadmium for a long period of time can accumulate in the body, especially the liver and kidneys [6]. This in turn can lead to breast cancer, respiratory problems, kidney failure and lead to death [7].

Cadmium in sea and river water comes from domestic and industrial waste pollution. Industries that can produce cadmium $(\mathrm{Cd})$ waste are the textile, battery, paint, plastic industry and others that can be a source of water pollution. According to WHO cadmium (Cd) water can be spread as far as $50 \mathrm{~km}$ from the source. WHO also declare that health effect of cadmium in drinking water has a Maximum Contaminant Level (MCL) of 0.005 milligrams per liter $(\mathrm{mg} / \mathrm{L})$ [8]. Research conducted in the waters of the western part of the Bay of Jakarta found that the content of cadmium $(\mathrm{Cd})$ exceeded the seawater quality standard was $0.47 \mathrm{mg} / \mathrm{l}[6]$.

Heavy metal that pollutes various waters variety, one of which is metal cadmium. Cadmium $(\mathrm{Cd})$ is absorbed by aquatic animals through the gills and digestive tract. Due to its toxic properties, this metal can be deadly. If the aquatic animal is resistant to high metal content, cadmium metal can accumulate in its tissues, especially the liver and kidneys. Cadmium metal binds to proteins so that it is called metallotionin which is somewhat permanent and has a fairly long half-life. Cadmium metal in into the body with food consumed. Metal poisoning chronic cadmium can cause system disturbance urinary, circulatory system and heart, reproduction and fragility on bone [9].

Cadmium is a metal that can be biotransformed and bioaccumulated in living beings (plants, animals and humans). The amount of metal that has accumulated in the bodies of aquatic biota will continue to rise. The amount of cadmium $(\mathrm{Cd})$ that accumulates is also determined by the level of native biota in the food 
chain system. There will be greater cadmium $(\mathrm{Cd})$ accumulation in the biota with higher strata, whereas the top-level biota will have the most accumulation. The biota of a level or strata will die and even be destroyed if the amount of cadmium (Cd) that enters above the threshold [10]. Green shellfish (Perna viridis) is a natural resource that has economic value and contains a lot of protein which is often consumed by humans. Therefore, these shells must be preserved and a biological research needs to be carried out by knowing the heavy metals that have accumulated in their bodies [11].

Previous research conducted at the Central Java Provincial Health Laboratory Center on types of shellfish market in Semarang contained the heavy metal cadmium of $1.285 \mathrm{ppm}$. These results indicate that the metal cadmium (Cd) in shellfish exceeds the threshold set by the ILO/WHO in marine animals; in this case the heavy metal content of cadmium $(\mathrm{Cd})$ in green shellfish that can be consumed by humans is $0.1 \mathrm{ppm}$. It stated that there was a decrease in cadmium $(\mathrm{Cd})$ levels in the green shellfish meat, which was originally $0.695 \mathrm{ppm}$. After soaking for one hour with $30 \%$ lime solution, the cadmium levels in the green shellfish decreased to $0.417 \mathrm{ppm}[12]$.

The solution which can be conducted by the consumer is to reduce cadmium metal (Cd), that is, with lime solution soaking (Citrus aurantifolia). Lime (Citrus aurantifolia) other than as fragrance enhancer and remover the fishy smell turns out to be usable as a reducing agent for heavy metals because it contains citric acid lime can be used as a heavy metal reducer because it contains organic acid compounds, namely citric acid. Citric acid present in lime can function as a compound that binds heavy metals in shellfish meat. The metal ions lose their ionic characteristics and the heavy metal loses much of its toxicity as a result of the reaction between the heavy metal binder (lime solution) and metal ions [13]. The purpose of this study was to determine if soaking lime for a longer period of time reduced levels of the heavy metal cadmium $(\mathrm{Cd})$ in green shellfish.

\section{RESEARCH METHOD}

This study used an experimental method with the type of True Experimental Design with a PretestPosttest Group Design approach. In this study there was no comparison group (control), but at least the first observation (pretest) had been carried out. Then after being given treatment to the sample, a cross-sectional posttest was carried out, namely the variables being studied were measured and collected in a certain point in time. To determine the number of samples using the Federer formula in order to obtain the required number of samples 24 samples were divided into four groups treated with a $30 \%$ concentration of the lime solution.

Sample preparation and testing of cadmium (Cd) levels in green shellfish (Perna viridis) were carried out at the Advanced Mineral and Material Laboratory of State University of Malang. The cadmium level was measured by atomic absorption spectrophotometry (AAS). The cadmium level of shellfish was tested before and after the lime solution soaking by Indonesian National Standard (SNI) Number 7387 of 2009 concerning the Maximum Limit of Heavy Metal Contamination in Food below one ppm. The lime solution was made by squeezing the lime fruit until $30 \mathrm{ml}$ of lime juice was obtained and then mixed with 70 $\mathrm{ml}$ of distilled water to obtain a concentration of the lime solution by $30 \%$.

Green shellfish are obtained from one of the traditional market, Surabaya City. Preparation of the shells was carried out by washing, refining and weighing each of them divided into 50 grams of the sample. The measurement of cadmium levels in the sample was carried out by laboratory testing. Then the other sample group was carried out experimentally by immersing 30\% concentration of the lime solution with different immersion times. Group I was soaking the lime for 15 minutes; Group II was soaking the lime for 30 minutes; Group III was soaking the lime for 60 minutes; Group IV was soaking the lime for 120 minutes. After immersion, a laboratory test was carried out to measure the cadmium content of each sample group.

Data analysis was performed by univariate and bivariate. Univariate data analysis, namely by calculating the average, standard deviation and maximum and minimum values. Bivariate data analysis was carried out by testing the difference in the average reduction in cadmium $(\mathrm{Cd})$ levels with the One-Way Anova parametic statistical test on condition that if the data were normal and homogeneous and if the data did not meet the requirements then using the Kruskal Wallis non-parametric statistical test with a significance level of $95 \%$. The effectiveness of the test can be determined through the Mann Whitney test.

\section{RESULTS AND DISCUSSION}

The lime solution contains elements of chemical compounds including citric acid, amino acids (tryptophan and lysine), carbonic acid, resin essential oils, glycosides, fats, calcium, phosphorus, iron, sulfur, vitamin B1 and vitamin C. in lime as much as 7-7.6\% [14]. Citric acid can dissolve polar compounds such as inorganic salts and sugars as well as non-polar compounds such as oil and metal elements/compounds (including cadmium). For this reason, efforts need to be made to reduce cadmium levels in green shellfish to 
be safe for human consumption. One of these efforts is to use metal binders or so-called chelating agents, including citric acid and acetic acid.

The average value of cadmium $(\mathrm{Cd})$ levels in green shellfish produced in the study was $0.0239 \mathrm{ppm}$ where this value did not exceed the threshold set by the Indonesian National Standardization Agency Number 7387 of 2009 concerning the Maximum Limit of Heavy Metal Contamination in Food, stated that the permissible levels of heavy metals in shellfish that can be consumed by humans for cadmium $(\mathrm{Cd})$ are not more than one ppm. For this reason, efforts need to be made to reduce cadmium levels in shellfish so that it is safe for human consumption if the levels are outside this threshold.

\subsection{Cadmium levels in shellfish}

The cadmium content in green shellfish before soaking the lime is $0.0324 \mathrm{ppm}$. Indonesian National Standard (SNI) Number 7387 of 2009 concerning the Maximum Limit of Heavy Metal Contamination in Food, it means the content of heavy metals from the results of the inspection still meets health requirements (below one ppm). The average cadmium levels after immersion can be shown in Table 1.

Table 1. The average cadmium levels in shellfish after soaking the lime solution

\begin{tabular}{lc}
\hline \multicolumn{1}{c}{ Soaking time } & Mean \\
\hline Soaking 15 minutes & $0.0285 \pm 0.0019$ \\
Soaking 30 minutes & $0.0245 \pm 0.0061$ \\
Soaking 60 minutes & $0.0194 \pm 0.0037$ \\
Soaking 120 minutes & $0.0084 \pm 0.0054$ \\
\hline
\end{tabular}

The following is a table of the percentage reduction in cadmium levels in green shellfish. Table 2 presents the magnitude of the decrease in cadmium levels in shellfish the most in immersion for 120 minutes, amounting to $73.77 \%$. This study is in accordance with previous research which states that there is a decrease in cadmium levels either with or without the addition of lime. Soaking using plain water can reduce mercury and cadmium levels in proportion to the length of soaking, but soaking with lime juice is much more effective [15]. The results of the reduction in cadmium levels were obtained by calculating the difference in cadmium levels before and after immersion in accordance with Figure 1.

Table 2. The percentage of decreased cadmium levels in shellfish after soaking the lime solution

\begin{tabular}{lc}
\hline \multicolumn{1}{c}{ Soaking time } & Percentage (\%) \\
\hline Soaking 15 minutes & 11.73 \\
Soaking 30 minutes & 24.07 \\
Soaking 60 minutes & 39.81 \\
Soaking 120 minutes & 73.77 \\
\hline
\end{tabular}

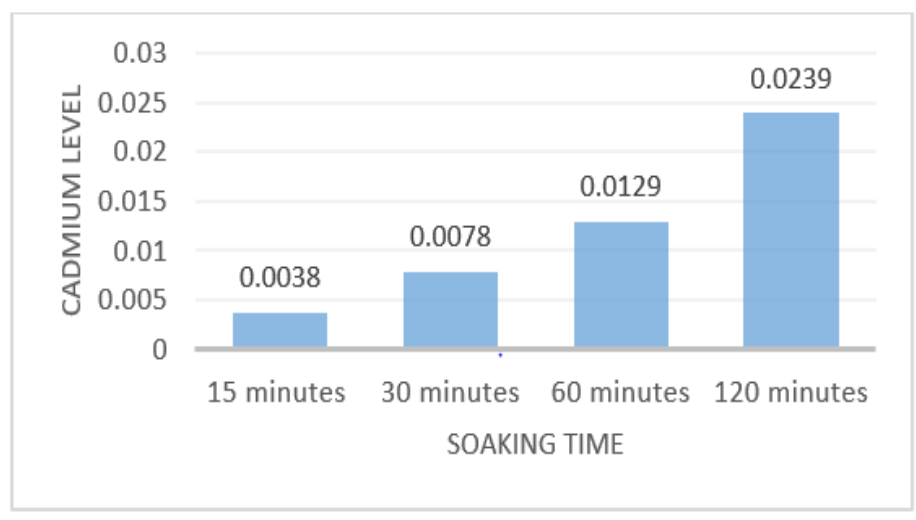

Figure 1. Decreasing in cadmium levels in green shellfish due to soaking of the lime solution

This study compared the levels of cadmium $(\mathrm{Cd})$ in green shellfish before and after soaking the lime solution. Cadmium levels in green shellfish decreased with the length of soaking time. Soaking the lime solution for 15 minutes with an average of 0.0038 , while 30 minutes with an average of $0.0078 ; 60$ minutes 
with an average of $0.0129 ; 120$ minutes with an average of 0.0239 . The lowest decrease was soaking the lime for 15 minutes; while the longer the lime soaking was for 120 minutes, the more the cadmium level decreased in the green shellfish. This study examined the levels of cadmium $(\mathrm{Cd})$ in green shellfish. After soaking the lime solution, the levels of cadmium in green shellfish decreased with the length of soaking time. This research present that acid solutions can damage the metal-protein complex bonds, besides that $\mathrm{Cd}$ metal also has fat soluble properties so that by immersion in an acid solution, the fat will form a smooth emulsion and dissolve in acid solution by dissolving fat in shellfish will also indirectly dissolve heavy metal levels. In this study, the indicator used to determine the decrease in heavy metals was cadmium in green shellfish.

Organoleptic research in the previous research states that there are changes in color, smell and taste of shell meat soaked for 60 minutes. After physically observing the shells soaked using lime juice $15 \%$, the changes in taste, color and smell were obtained in the shells soaked in lime juice for 60 minutes. The shells that are soaked for 60 minutes turn sour and have a slightly pale color [16]. This is influenced by the length of time that the shells are soaked with lime juice so that the citric acid, amino acids and citrus acids contained in the lime juice absorb into the shellfish, giving rise to a sour taste and change the color of the shellfish from the original. Therefore, the duration of soaking lime in shellfish must be considered and a solution is sought to overcome the negative physical effects after soaking the lime.

\subsection{The soaking time effectiveness of lime solution}

The average of cadmium level was taken from the results of the laboratory test to determine the levels of cadmium (Cd) in green shellfish after soaking the lime solution with different soaking times. Data is said to be normal if the significance is $>0.05$ and if the data is not normal then the significance is $<0.05$. The data of this study were normal with p-values of 0.821 and 0.498 . Henceforth, the homogeneity test was carried out with a p-value of 0.004 meaning that the data was not homogeneous, so the Kruskal Wallis test was then carried out.

The Kruskal Wallis test is a non-parametric test in the procedure group for independent samples which is used to determine the existence of a statistically significant difference between two or more groups of independent variables on the dependent variable with a numeric data scale (interval/ratio) and an ordinal scale. With this test, the resulting p-value is 0.001 . This means that there is a difference between the effect of the duration of immersion and the decrease in cadmium $(\mathrm{Cd})$ in green shellfish. Furthermore, statistical analysis was carried out using the Mann Whitney test. The Mann Whitney test is a test to determine whether there is a real difference between the mean of two populations that have the same distribution, through two independent samples taken from the two populations. With the Mann Whitney test, we will be able to find out which sample group is more effective at reducing cadmium levels in green shellfish.

Table 3. The effectiveness of lime soaking time using Mann Whitney test results

\begin{tabular}{cc}
\hline Group & $\mathrm{p}$-value \\
\hline Group 1 (15 minutes) + Group 2 ( 30 minutes) & 0.518 \\
Group 1 (15 minutes) + Group 3 (60 minutes) & 0.004 \\
Group 1 (15 minutes) + Group 4 (120 minutes) & 0.004 \\
Group 2 (30 minutes) + Group 3 (60 minutes) & 0.171 \\
Group 2 (30 minutes) + Group 4 (120 minutes) & 0.004 \\
Group 3 (60 minutes) + Group 4 (120 minutes) & 0.008 \\
\hline
\end{tabular}

Based on Table 3, it is known that the best effectiveness of soaking the $30 \%$ lime solution is 120 minutes. With the results of the p-value of immersion for 120 minutes, namely $<0.05$, it can be stated that immersion for 120 minutes is more effective. This is in accordance with previous research that the longer the lime juice is immersed, the more effective it is to reduce the lead $(\mathrm{Pb})$ levels in beef [17]. Waste lemonextract flushing eliminated much more metals. This is due to the fact that the waste lemon-extract solution contains more co-dissolved organic compounds with a longer flushing duration, allowing for more exchange reactions between adsorbed metals and the flushing solution [17], [18].

Organic acid metabolism is extremely important at both the cellular and plant levels. Organic acids' involvement in modifying adaptation to the environment, especially their engagement in heavy metal detoxification, has gotten a lot of attention in recent years. Metal chelatation with carboxyl groups allows acids like citrate, malate, oxalate, malonate, aconitate, and tartrate to create strong form bonds with heavy metal ions. In metal ligands, it served as a donor of oxygen [19], [20].

Citric acid is found in the highest concentrations in lime solution, which has $1.38 \mathrm{~g} / 100 \mathrm{~g}$. Lime juice concentrations range from $1.06 \mathrm{~g} / 100 \mathrm{~g}$ to $1.06 \mathrm{~g} / 100 \mathrm{~g}$. Citric acid (also known as 2-hydroxy-1,2,3propanetricarboxylic acid) is a weak tricarboxylic acid found in citrus fruits. Citric acid is a common food 
additive that adds acidity and a sour flavor to foods and beverages. Citric acid can be used in food coloring to bring a naturally basic dye's pH level back into balance. Minerals are delivered in biologically accessible forms using citrate salts of various metals; examples include dietary supplements and pharmaceuticals. Lemons and limes have the highest concentration of citric acid among fruits, for up to $8 \%$ of the dry fruit weight [21].

The ability of the lime solution to reduce cadmium $(\mathrm{Cd})$ levels in green shellfish is due to the presence of citric acid in the lime solution. Citric acid is a squestrant substance (metal binding agent). Citric acid has the chemical formula $\mathrm{CH} 2 \mathrm{COOH}-\mathrm{COHCOOH}-\mathrm{CH} 2 \mathrm{COOH}(\mathrm{C} 6 \mathrm{H} 8 \mathrm{O} 7)$. The $-\mathrm{OH}$ and $\mathrm{COOH}$ functional groups in citric acid cause citrate ions to react with metal ions to form citrate salts [15]. Citrate ions bind to metals so they can remove metal ions that accumulate in shellfish as citrate complexes [15], [22]. The higher the concentration of a solution, the more quickly the solution to react with other compounds. Likewise with the immersion time. The longer a substance interacts with other compounds, the faster the reaction between citric acid and metals.

The toxic properties of heavy metals are bound to sulfhydryl groups (SH) in enzymes such as cysteine carboxyl, histidyl, hydroxyl, and phosphatyl from proteins and purines. The toxicity and lethality of the heavy metal lead in the body of aquatic biota (shellfish) can be eliminated by adding a solution of citric acid. Heavy metals connect to atoms with free ions, whereas citric acid contains four free electrons in the carboxylic group, allowing complex interactions to form (metal binders). Metal binders react with metal ions via coordination bonds, causing the metal ions to lose their ionic characteristics and the heavy metal to lose the majority of its toxicity [13].

In living organisms, cadmium will undergo biotransformation and bioaccumulation mechanisms (plants, animals and humans). This metal enters the body through food, which has been tainted with metal cadmium $(\mathrm{Cd})$. The quantity of metal that accumulates in the bodies of aquatic biota will continue to rise. Furthermore, the amount of cadmium $(\mathrm{Cd})$ that accumulates is determined by the level of biota in the food chain system. There will be more cadmium accumulation in the higher strata biota $(\mathrm{Cd})$. The biota will die and even be destroyed if the amount of Cadmium $(\mathrm{Cd})$ that enters above the threshold. It can decrease growth, cause lung cancer, nausea, vomiting, diarrhea, cramps, anemia, dermatitis, sluggish growth, kidney and liver damage, and cardiovascular issues if it accumulates for a long time. Cadmium can also cause bone loss (osteomalacia, osteoporosis) and blood pressure to rise. Chest pain, shortness of breath (shortness of breath), coughing, and weakness are all common signs of cadmium poisoning [23].

The citric acid in the lime solution dramatically reduced cadmium levels. Citric acid, when compared to other organic acids like oxalic, malic, and tartaric acids, has the greatest capacity for desorbing heavy metals [24]. Furthermore, adding citric acid reduced $\mathrm{Pb}$ by 96.1-97 percent and cadmium by 97.5$98.9 \%$, according to the findings. Citric acid concentration increased, while oxidizable content dropped, indicating that citric acid could boost heavy metal bioavailability [25], [26].

Previous studies in soil found that a high concentration of citric acid has a significant impact on heavy metals in the soil. This could be because low concentrations of citric acid can adsorb on soil, increasing heavy metal adsorption sites, whereas high concentrations of citric acid will bring a large number of hydrogen ions into the soil, causing heavy metal desorption and thus increasing heavy metal concentrations [27]. Heavy metal levels were reduced by soaking shellfish meat in lime juice. The more time shellfish is soaked in lime juice, the lower the heavy metal levels decrease. The longer the shell in soak with lime juice then the heavy metal levels decreases. This decrease is due to the long soaking time the metal contact with the acid is also longer, so acid has a long chance to bind the metal. The longer time soaking the more contact between metal with acid so that the acid chance to bind the metal is getting bigger. The influence of long interaction soaking of lime solution decrease levels of heavy metal lead $(\mathrm{Pb})$ on shellfish. The longer the soaking time, the heavy metal levels of $\mathrm{Pb}$ on the mussel meat decreases. Aquadest also can decrease heavy metal in shells but aquadest does not have the capability to bind metals as well as the lime solution. Aquadest is only capable to dissolve and precipitate heavy metal levels on the surface of clam meat or in direct contact with the aquadest. The decrease in heavy metal levels after soaking with aquadest is also caused by water which can damage the complex bonds of protein metals although not as effective as citric acid [28].

Citric acid proved effective at saturating heavy metals and causing their absorption. Commercial citric acid is recommended for reducing heavy metals in food ingredients since it is ecologically benign and cost effective. The optimal addition of citric acid to reduce the amount of heavy metals $(\mathrm{Pb}$ and $\mathrm{Cd})$ is at a concentration of 26.6 percent [13], which we employed in this study at a concentration of 30 percent lime solution. The higher a solution's concentration, the more quickly it reacts with other compounds. The same can be said for the soaking time. The reaction between citric acid and metals is faster the longer a material interacts with other chemicals. This study found that the length of time spent soaking in lime solution had a substantial impact on the decrease of metals in shellfish, particularly cadmium. According to this study, there 
is a temporal difference that has a significant impact on reducing cadmium $(\mathrm{Cd})$ levels in green shellfish. Furthermore, seafood generated from shellfish should be developed and made safe to eat as a complex source of animal protein. According to prior research, 102 healthy men and women aged 48 to 76 years old consumed one kilogram of mussel every week for 26 weeks and had no concerns about $\mathrm{Hg}$, As, or Cd levels in their blood. Heavy metal concentrations in six commercial cephalopod species in South Korea were in the following order: $\mathrm{Al}>\mathrm{As}>\mathrm{Cd}>\mathrm{Pb}>\mathrm{Hg}$. All of the metal contents complied with regulatory requirements and posed no risk to customers [29].

\section{CONCLUSION}

The decrease in cadmium levels in green shellfish was influenced by the length of soaking the lime solution. This is caused by the presence of citric acid in lime which plays a role in binding cadmium metal. The longer the soaking time, the longer the time for the citrate ions to react with metal cadmium so that more cadmium is bound to the lime solution. Soaking the green shellfish in the lime solution will be more effective with the length of soaking time. By the lime solution soaking, the cadmium level of the shellfish meat contains cadmium $(\mathrm{Cd})$ which does not exceed the standard determined by the Indonesian National Standard number 7387 of 2009 concerning the Maximum Limit of Heavy Metal Contamination in Food, so it is safer as a more economical source of marine animal protein.

\section{REFERENCES}

[1] V. Venugopal and K. Gopakumar "Shellfish: Nutritive Value, Health Benefits, and Consumer Safety," Comprehensive Reviews in Food Science and Food Safety, vol. 16, no. 16, pp. 1219-1242, 2017, doi: 10.1111/1541-4337.12312.

[2] JL. Domingo, "Nutrients and chemical pollutants in fish and shellfish: balancing health benefits and risks of regular fish consumption," Crit Rev Food Sci Nut, vol. 56, no. 6, pp. 979-88, 2016, doi: 10.1080/10408398.2012.742985.

[3] Food and Agriculture Organization/World Health Organization (FAO/WHO), "Toxicity equivalency factors for marine biotoxins associated with bivalve mollusks," p. 108 2016, [Online]. Available: http://www.fao.org/3/ai5970e.pdf.

[4] ECsafeSEAFOOD, "Priority environmental contaminants in seafood," 2017, [Online]. Available: http://www.ecsafeseafooddbase.eu/.

[5] Kementrian Kelautan dan Perikanan Republik Indonesia, "Indonesian fisheries productivity: exposure at the 9th independent west forum", Jakarta, January 19 2018, [Online]. Available: https://kkp.go.id/wpcontent/uploads/2018/01/KKP-Dirjen-PDSPKP-FMB-Kominfo-19-Januari-2018.pdf.

[6] M. Huhn, "The relevance of food availability for the tolerance to environmental stress in Asian green mussels, Perna viridis, from coastal habitats in Indonesia," Dissertation, Geomar Repository and Institut Pertanian Bogor, 2016.

[7] S. Syakri, "Analysis of Heavy Metal Cadmium (Cd) in Shellfish Circulating in Traditional Markets in Makassar City (In Indonesia: Analisis Logam Berat Kadmium (Cd) Dalam Kerang yang Beredar di Pasar Tradisional di Kota Makassar)," Journal Farmasi, vol. 4, no. 4, 2016.

[8] World Health Organization, "Cadmium in Drinking-water," 2011, [Online]. Available: https://www.who.int/water_sanitation_health/dwq/chemicals/cadmium.pdf.

[9] I. M. Dharmadewi, "Analysis of Leading Metal (Pb) and Cadmium (Cd) Content Green Shells (Perna viridis L.) in the Kreneng Market," Journal of Sustainable Development Science, vol. 2, no. 2, pp. 40-45, December 2020, doi: 10.46650/jsds.2.2.1008.40-45.

[10] R. A. Wuana, and F. E. Okieimen, "Heavy Metals in Contaminated Soils: A Review of Sources, Chemistry, Risks and Best Available Strategies for Remediation," International Scholarly Research Network ISRN Ecology, vol. 2011, pp. 1-21, doi: 10.5402/2011/402647.

[11] M. Nowrouzi, A. Pourkhabbaz, and M. Rezaei, "Bioaccumulation and Distribution of Metals in Sediments and Avicenna Marina Tissue in The Hara Biosphere Reserve, Iran,” Bull Environ Contarm Toxicol, vol. 89, no. 4, pp. 799-804, 2012, doi: 10.1007/s00128-012-0751-3.

[12] H. Ali, E. Khan, and I. Ilahi, "Environmental Chemistry and Ecotoxicology of Hazardous Heavy Metals: Environmental Persistence, Toxicity, and Bioaccumulation," Journal of Chemistry, vol. 2019, pp. 1-14, 2019, doi: $10.1155 / 2019 / 6730305$.

[13] Zaenab and Rafidah, "Effectiveness of Lime Juice (Citrus autrantifolia) to Decrease $\mathrm{Hg}, \mathrm{Cd}$ and Pb Levels in Shells Meat and White Shrimp," Dama Academic Cholarly Journal of Researchers, vol. 2, no.10, pp. 102-111, October, 2017.

[14] D. N. Purba, M.Ilza, and Edison, "The Lime Fluid (Citrus aurantifolia) Ability of Reduction Against Heavy Metals in Mussel (Meretrix meretrix) Kepah,” Journal Online Mahasiswa Fakultas Perikanan dan Ilmu Kelautan, vol 3, no. 1, pp. 1-10, 2016.

[15] Al-Snafi and A. Esmail, "Nutritional value and pharmacological importance of citrus species grown in Iraq," OSR Journal of Pharmacy, vol. 6, no. 8, pp. 76-108, 2016, doi: 10.9790/3013-0680176108. 
[16] H. Dheasy and Soedaryo, "The Effect of Soaking Blood Scallops (Anadara granosa) with Lime Juice on Levels of Mercury (Hg) and Cadmium (Cd) (In Indonesia: Pengaruh Perendaman Kerang Darah (Anadara granosa) dengan Perasan Jeruk Nipis Terhadap Kadar Merkuri (Hg) dan Kadmium (Cd)," Jurnal SainHealth, vol. 1, no. 1, pp. 3035, 2017 doi: 10.51804/jsh.v1i1.75.30-35.

[17] Nurmalasari dan Zaenab, "Utilization of Lime Juice (Citrus autrantifolia swingle) in Reducing Levels of Heavy Metal Pb Contained in Shellfish Meat," Dama International Journal of Researchers, vol. 2, no. 10, pp. 102-111, October, 2017.

[18] Masduqi, Mahbub dan S. Ngabekti, "Effect of Soaking Time and Concentration of Lime Juice on Reduction of Lead $(\mathrm{Pb})$ Levels in Beef," Unnes Journal of Life Science, vol. 4, no. 1, pp. 45-53, 2015.

[19] Y.Yan, J.Gao, J. Wu, and B. Li, "Effects of Inorganic and Organic Acids on Heavy Metals Leaching in Contaminated Sediment," An Interdisciplinary Response to Mine Water Challenges - Sui, Sun \& Wang (eds) (C)2014 China University of Mining and Technology Press, Xuzhou, 2014.

[20] Pei-Wen Zhang, Ya-Zhen Huang, Chihhao Fan and Tsun-Kuo Chang, "Application of Waste Lemon Extract to Toxic Metal Removal through Gravitational Soil Flushing and Composting Stabilization”, Sustainability, vol. 12, no. 14, p. 5751, 2020, doi:10.3390/su12145751.

[21] Apleblat, Alexander, "Citric acid," Springer. 2014.

[22] N. Osmolovskaya, V. V. Dung, and L. Kuchaeva, "The Role of Organic Acids in Heavy Metal Tolerance in Plants," Bio. Comm., vol. 63, no. 1, pp. 9-16, 2018, doi: 10.21638/spbu03.2018.103.

[23] H. Lu et.al, "Low Molecular Weight Organic Acids Increase Cd Accumulation in Sunflowers through Increasing Cd Bioavailability and Reducing Cd Toxicity to Plants," Minerals, vol. 11, no. 3, pp. 1-19, 2021, doi: 10.3390/min 11030243 .

[24] S. Najafi and M. Jalali, "Effects of Organic Acids on Cadmium and Copper Sorption and Desorption by Two Calcareous Soils," Journal Environ Monit Assess, vol. 187, no. 9, 2015, doi: 10.1007/s10661-015-4804-z.

[25] G. Genchi, M. S. Sinicropi, G. Lauria, A. Carocci, and A. Catalano, "The Effects of Cadmium Toxicity," Int J Environ Res Public Health. vol. 17, no. 11, p. 3782, 2020, doi: 10.3390/ijerph17113782.

[26] M. B. Massoud, L. Sakouhi, and A. Chaoui, "Effect of plant growth regulators, calcium and citric acid on copper toxicity in pea seedlings," $J$ Plant Nutr., vol. 42, no. 10, pp. 1230-1242, 2019, doi: 10.1080/01904167.2019.1609506.

[27] G. Liu, "Effect of Citric Acid on Immobilization of Heavy Metals," IOP Conference Series: Earth and Environmental Science, vol. 242, no. 5, 2019, pp. 1-6, doi: 10.1088/1755-1315/242/5/052020.

[28] Indasah, A. Arbai, Sugijanto, and S. Agus, "Citric acid reduces the content of $\mathrm{Pb}$ and $\mathrm{Cd}$ of Kupang Beras (Corbula Faba)," Folia Medica Indonesiana, vol. 47, no. 1, pp. 46-51, 2011.

[29] Y. Nho, N. Khan, JY. Choi, JS. Kim, KS. Park, and KS. Kim, "Determination of toxic metals in cephalopods from South Korea," Anal Lett, vol. 49, no. 10, pp. 1578-1588, 2016. 